\title{
点支持された斜板の有限要素法による解析

\author{
ANALYSIS OF POINTS-SUPPORTED SKEW PLATES \\ BY FINITE ELEMENT METHOD
}

\begin{abstract}
川島一彦*・関 千秋** ・梶田建夫*** ・成岡昌夫**** By Kazuhiko Kawashima, Chiaki Seki, Tateo Kajita aud Masao Naruoka
\end{abstract}

\section{1.はしがき}

斜板に関しては，これまで多くの模型実験や差分法 ${ }^{4)}$ による数值解析が行なわれてきており，斜板が長方形板 とは相当異なった力学的挙動を示すことは, 広く知られ ている。しかし, 現在までに行なわれた研究の多くは, 曲げモーメントに関するものであり, 支点の反力を実験 的に取り扱っているものもあるが，これは比較的少な (2),3),5)。また，支 点の反力を取り扱っ ているものでも, 支 点での沈下や浮き上 りを許さない, いわ ゆる，剖に支持され た場合を対象として いるものが大部分で あるが, 実際の斜板 構造物は適当な間隔 をおいて並べられた ネオプレーンなどの ゴム支承で, 弾性的, かつ, 非連続的に支 持されていることが 多い。このよらに, 斜板が弾性的に数点 で支持されている場 合には，板に複雑な 変形を与えると考え られるが,こうした 斜板の豲密な理論的

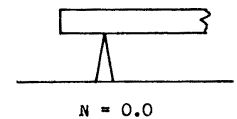

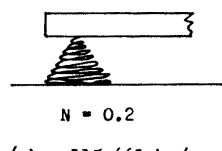

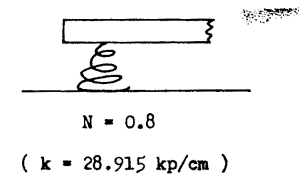

$$
(\mathrm{k}=115.661 \mathrm{kp} / \mathrm{cm})(\mathrm{k}=28.915 \mathrm{kp} / \mathrm{cm})
$$

弹性的柔軟度

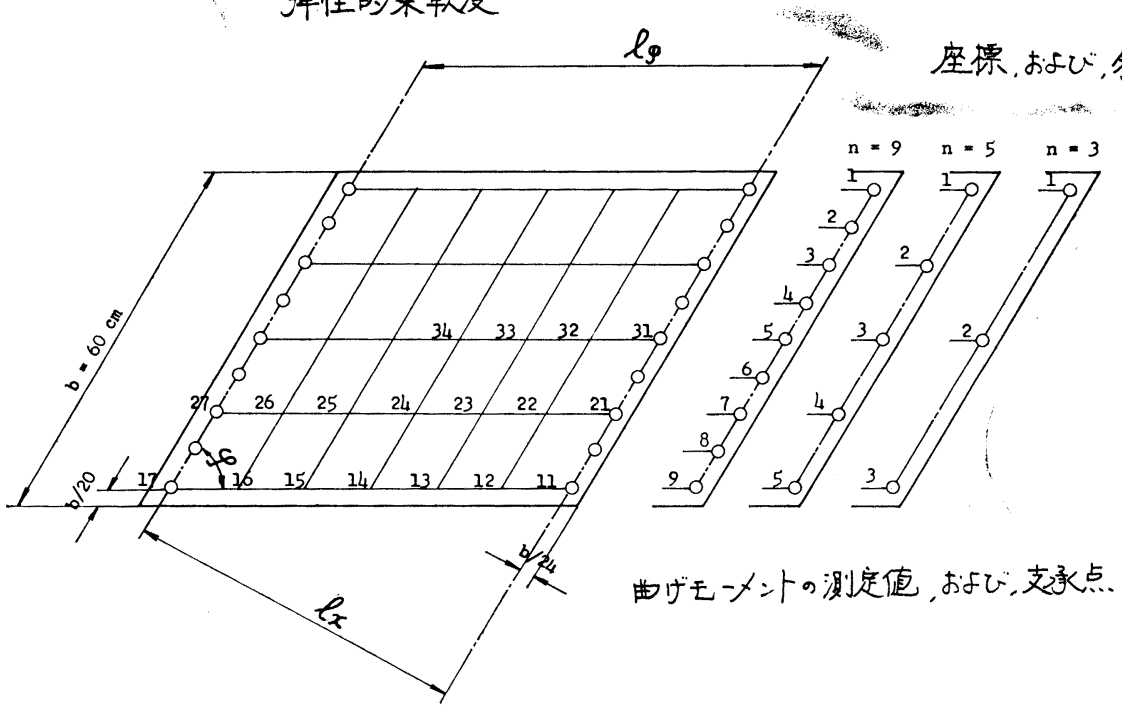

図一1 実験に用いられた模型
解析は，非常に困難である。

Darmstadt 工科大学の A. Mehmel 教授と, その助 手 H. Weise は, 種々の条件の斜板について, 実験的 研究を行ない, 斜板の支点反力, 曲げモーメントの性質 について研究している1)。このような問題は, 現在, 有 限要素法を用いることにより，容易に数值解析されらる ことに着目し，A. Mehmel らの実験報告にそった数值 解析を行なったので, この数值解析結果と実験值との比 較，および結果の検討について報告したい。 


\section{A. Mehmel らの行なった実験的研究の概要}

A. Mehmel と H. Weise は, 図一1 のような相対 する 2 辺で弾性的に点支持され，他の 2 辺が自由である 斜板の, 支点反力, および, 曲げモーメント, 㸚じりモ一 メントに影響をおよぼす因子として, 斜角, 辺長比, 弾 性的柔軟度, 支点数の 4 つを取りあげ; それぞれ，つぎ に示すように 3 種類ずつ, 合計 $3^{4}=81$ 種類にわたって, 組織的な実験を行なった。これらは, 満載等分布荷重が 作用したときの支点反力と曲げモーメント，および，支 点反力の影響面の形で報告されている。

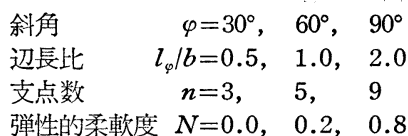

ここで, 辺長此 $l_{\varphi} / b$ とは, 自由辺の長さ, すなわち, 斜板のスパン $l_{\varphi}$ と支承線方向の幅員 $b$ との比であり, Mehmel らの実験では, $b$ を統一して, $60 \mathrm{~cm}$ にとっ ている。また, 支承の弾性的柔軟度 $N$ (elastische-Nachgiebigkeit）は，つぎのように定義されている。

$$
N=E d^{3} / k b^{2}
$$

ここで, $E$ : 板材料のヤング係数, $d:$ 板の厚さ, $b:$ 板 の支承線方向の幅員, $k$ : 支承材料のばね定数である。 また，実験に用いられた模型の材料は水晶ガラスで，厚 さ $d=0.48 \mathrm{~cm}$, ヤング係数 $E=753000 \mathrm{kp} / \mathrm{cm}^{2}$, ポアソ ン比 $\mu=0.22$ である。

\section{3. 有限要素法による解析}

\section{(1) 使用した要素}

図一1のような斜板を要素に分割するには，三角形要 素に分割する方法と平行四辺形要素に分割する方法とが 考えられる。ここでは, これら両方の分割法を使用し た。

三角形要素としては，O.C. Zienkiewicz らによる一 節点の变位成分が, $w, \theta_{x}(=-\partial w / \partial y), \theta_{y}(=\partial w / \partial x)$ の 3 個で，隣接要素間のたわみ角の連続性のない，いわ ゆる, non-conforming の形のものを使用した ${ }^{6}$ 。

また，平行四辺形要素としては，たわみ に対応した斜交座標を用いて，長方形要素に対して行な われたと同様に, 12 の項数をもつ多項式で仮定したも のを用いた。

\section{(2) 支点反力}

剛に支持されている場合には，境界条件として，その 支点でのたわみ $w$ を淿する。全体の変位 $\{U\}$ は，
このように境異条件で与えられる既知の変位 $\left\{U_{\alpha}\right\}$ と， 未知の変位 $\left\{U_{\beta}\right\}$ とに分けることができる。同様に，力 $\{F\}$ も， $\left\{U_{\alpha}\right\}$ に対応する力 $\left\{F_{\alpha}\right\}$ と， $\left\{U_{\beta}\right\}$ に対応す る力 $\left\{F_{\beta}\right\}$ とに分けられる。力 $\left\{F_{\alpha}, F_{\beta}\right\}^{T}$ と変位 $\left\{U_{\alpha}\right.$, $\left.U_{\beta}\right\}^{T}$ とは, Stiffness Matrix により，つぎのように結 びつけられる。

$$
\left\{\begin{array}{c}
F_{\alpha} \\
\hdashline F_{\beta}
\end{array}\right\}=\left[\begin{array}{c:c}
K_{\alpha \alpha} & K_{\alpha \beta} \\
\hdashline K_{\beta \alpha} & K_{\beta \beta}
\end{array}\right]\left\{\begin{array}{c}
U_{\alpha} \\
\hdashline U_{\beta}
\end{array}\right\}
$$

いま, $\left\{U_{\alpha}\right\}=0$ であるから，末知変位 $\left\{U_{\beta}\right\}$ は

$$
\left\{U_{\beta}\right\}=\left[K_{\beta \beta}\right]^{-1}\left\{F_{\beta}\right\}
$$

$\therefore\left\{F_{\alpha}\right\}=\left[K_{\alpha \beta}\right]\left[K_{\beta \beta}\right]^{-1}\left\{F_{\beta}\right\}$

となる。この $\left\{F_{\alpha}\right\}$ が支点反力である。

つぎに，弾性的に支持されている場合には，支点のば 补定数 $k$ を，全体の Stiffness Matrix の対応する対角 要素 (ここでは, ばね沈沈下，あるいは，浮き上りに対 してのみ作用し，回転には無拘束とした）に加えてか ら,この行列の逆行列を求める。これから, 各節点での 変位が求められると, 支点反力は, 支点の变位にばね定 数 $k$ を乘じたものとなる。

\section{（3）要素の分割}

A. Mehmel らの実験に用いられた模型には，図一1 のよ5に, 自由辺, 支持辺に, それぞれ, $b / 20, b / 24$ の 張り出し部がついているが, 計算では, これらを無視し て，四隅の支承点を結ぶ線の範囲内を対象とした。

要素の分割数は, 支点反力を求めるためには, 辺長比 $l_{\varphi} / b=0.5$ の場合, 45 節点（支持辺，自由辺を，それぞ れ， 8,4 等分に分割一以下，これを “ $8 \times 4 ”$ のように 表わす) に, $l_{\varphi} / b=1.0$ の場合には, 35 節点 $(4 \times 6)$, $l_{\varphi} / b=2.0$ の場合には, 55 節点 $(4 \times 10)$ とした。曲げ モーメントについては, $l_{\varphi} / b=1.0$ の場合を対象として, 支点反力を求める場合より細かく分割して，63 節点 $(8$ ×6)とした。

\section{4. 実験値と計算値との比較}

満載等分布荷重が作用したときの各支点反力について は，表一1 に示すように，11 種類の場合を計算した。 各段とも, 上が著者らの計算結果を，下の（）内が, A. Mehmel らの実験值を示している。

これによれば，計算值は，鈍角端のように反力の集中 する支点では，やや実験值よりも小さめになっているほ かは, きわめて実験值とよく一致していると思われる。

支点反力の影響面の計算值を, 実験による影響面の值 と比較した例が，図一2，および，図一3である。図一2 は弾性的柔軟度 $N$ を, 図一3 は支点数 $n$ を, それぞ れ変化させたときの，影響面の変化を表わしている。等 
表一1 等分布荷重 (q) 㴖䇅の場合の支点反力 $\{\boldsymbol{q} \times$ 板の面榬を 1 とする $\}$

a) 辺長比 $l_{\varphi} / b=1.0$, 斜角 $\varphi=60^{\circ}$, 支点数 $n=5$

\begin{tabular}{|c|c|c|c|c|c|c|}
\hline \multirow{2}{*}{$\varphi$} & \multirow{2}{*}{$N$} & \multicolumn{2}{|c|}{ 支 } & \multirow{2}{*}{$\begin{array}{r}\text { 点 } \\
3\end{array}$} & $(n=5)$ & \multirow[b]{2}{*}{5} \\
\hline & & 1 & 2 & & 4 & \\
\hline \multirow{3}{*}{$60^{\circ}$} & 0.8 & $\begin{array}{c}0.048 \\
(0.051)\end{array}$ & $\begin{array}{c}0.086 \\
(0.073)\end{array}$ & $\begin{array}{c}0.107 \\
(0.099)\end{array}$ & $\begin{array}{c}0.121 \\
(0.124)\end{array}$ & $\begin{array}{c}0.139 \\
(0.153)\end{array}$ \\
\hline & 0.2 & $\begin{array}{c}0.042 \\
(0.046)\end{array}$ & $\begin{array}{c}0.081 \\
(0.075)\end{array}$ & $\begin{array}{c}0.099 \\
(0.092)\end{array}$ & $\begin{array}{c}0.114 \\
(0.113)\end{array}$ & $\begin{array}{c}0.162 \\
(0.174)\end{array}$ \\
\hline & 0.0 & $\begin{array}{c}0.023 \\
(0.039)\end{array}$ & $\begin{array}{c}0.097 \\
(0.103)\end{array}$ & $\begin{array}{c}0.125 \\
(0.092)\end{array}$ & $\begin{array}{c}0.075 \\
(0.052)\end{array}$ & $\begin{array}{c}0.180 \\
(0.214)\end{array}$ \\
\hline \multirow{3}{*}{$30^{\circ}$} & 0.8 & $\begin{array}{c}0.021 \\
(0.026)\end{array}$ & $\begin{array}{c}0.078 \\
(0.068)\end{array}$ & $\begin{array}{c}0.108 \\
(0.110)\end{array}$ & $\begin{array}{c}0.133 \\
(0.130)\end{array}$ & $\begin{array}{c}0.161 \\
(0.166)\end{array}$ \\
\hline & 0.2 & $\begin{array}{c}0.020 \\
(0.023)\end{array}$ & $\begin{array}{c}0.071 \\
(0.069)\end{array}$ & $\begin{array}{c}0.098 \\
(0.096)\end{array}$ & $\begin{array}{c}0.117 \\
(0.118)\end{array}$ & $\begin{array}{c}0.194 \\
(0.194)\end{array}$ \\
\hline & 0.0 & $\begin{array}{c}0.019 \\
(0.016)\end{array}$ & $\begin{array}{c}0.074 \\
(0.081)\end{array}$ & $\begin{array}{c}0.128 \\
(0.117)\end{array}$ & $\begin{array}{c}0.017 \\
(0.016)\end{array}$ & $\begin{array}{c}0.263 \\
(0.270)\end{array}$ \\
\hline
\end{tabular}

b) 辺長比 $l_{\varphi} / b=2.0$, 斜角 $\varphi=60^{\circ}$, 支点数 $n=5$

\begin{tabular}{|c|c|c|c|c|c|}
\hline \multirow{2}{*}{$N$} & \multicolumn{2}{|c|}{ 支 } & \multicolumn{3}{|c|}{$(n=5)$} \\
\hline & 1 & 2 & 3 & 4 & 5 \\
\hline 0.8 & $\begin{array}{c}0.014 \\
(0.017)\end{array}$ & $\begin{array}{c}0.055 \\
(0.050)\end{array}$ & $\begin{array}{c}0.088 \\
(0.087)\end{array}$ & $\begin{array}{c}0.133 \\
(0.134)\end{array}$ & $\begin{array}{c}0.212 \\
(0.212)\end{array}$ \\
\hline 0.2 & $\begin{array}{c}0.012 \\
(0.024)\end{array}$ & $\begin{array}{c}0.063 \\
(0.043)\end{array}$ & $\begin{array}{c}0.076 \\
(0.065)\end{array}$ & $\begin{array}{c}0.092 \\
(0.106)\end{array}$ & $\begin{array}{c}0.260 \\
(0.262)\end{array}$ \\
\hline
\end{tabular}

c) 辺長比 $l_{\varphi} / b=0.5$, 斜角 $\varphi=60^{\circ}$, 弾性的柔軟度 $N=0.2$

\begin{tabular}{|c|c|c|c|c|c|c|c|c|c|}
\hline \multirow{2}{*}{$\boldsymbol{n}$} & \multicolumn{4}{|c|}{ 支 } & \multicolumn{5}{|c|}{$(n=3,5,9)$} \\
\hline & 1 & 2 & 3 & 4 & 5 & 6 & 7 & 8 & 9 \\
\hline 3 & $\mid$\begin{tabular}{l|}
0.078 \\
$(0.093)$
\end{tabular} & $\mid \begin{array}{l}0.234 \\
(0.227)\end{array}$ & $\left|\begin{array}{c}0.171 \\
(0.180)\end{array}\right|$ & & & & & & \\
\hline 5 & $\left|\begin{array}{c}0.045 \\
(0.064)\end{array}\right|$ & $\mid \begin{array}{c}0.102 \\
(0.088)\end{array}$ & $\left|\begin{array}{c}0.122 \\
(0.111)\end{array}\right|$ & $\mid \begin{array}{c}0.123 \\
(0.113)\end{array}$ & $\mid \begin{array}{c}0.108 \\
(0.124)\end{array}$ & & & & \\
\hline 9 & $\left|\begin{array}{c}0.027 \\
(0.040)\end{array}\right|$ & $\begin{array}{l}0.043 \\
(0.045)\end{array}$ & $\left|\begin{array}{l}0.053 \\
(0.050)\end{array}\right|$ & $\mid \begin{array}{l}0.058 \\
(0.052)\end{array}$ & $\mid \begin{array}{l}0.060 \\
(0.054)\end{array}$ & \begin{tabular}{|l}
0.061 \\
$(0.054)$
\end{tabular} & $\mid \begin{array}{l}0.062 \\
(0.055)\end{array}$ & $\left|\begin{array}{l}0.065 \\
(0.065)\end{array}\right|$ & $\mid \begin{array}{l}0.074 \\
(0.085)\end{array}$ \\
\hline
\end{tabular}

高線の間隔は 単位荷重の 0.2 倍とし, 実線が計算結果 を, 破線が A. Mehmel らの実験值を示している。板 周辺の張り出し部を無視して計算しているので, 周辺部 において計算では現われてこない等高線が実験值の場合 にはあるが，全体としては，支点反力の影響面の計算結 果は, 実験値の傾向をよく表わしていると考えられる。

つぎに, 曲げモーメントについて少し述べよう。A.

Mehmel らの実験では, 影響面の形では報告されていな いので, 满載等分布荷重が作用した場合を, 辺長比 $l_{\varphi} / b$ $=1.0$, 斜角 $\varphi=30^{\circ}$, 支点数 $n=5$ の斜板について実験 值と比較したのが 表一2 である。表中の数值は, 図一1 に示されている，11〜34 の各点における曲げモーメン ト, $M_{x}, M_{y}$, および，ねじモーメント $M_{x y}$ のモーメ ント係数を表わしている。この表より, 計算值は実駼值 と定性的には，よく一致していると思われるが，定量的 には，さきの支点反力の場合に比較して，あまりよくな いよらである。この理由としては, 支点反力はたわみか
表一2 辺長比 $l_{\varphi} / b=1.0$, 斜角 $\varphi=30^{\circ}$, 支点数 $n=5$ の場 合における, 等分布荷重滿載時の, 点 11〜34（図一 1 参照) における曲げモーメントの值（単位 $q l_{x}^{2}$ ) \{C ）内は実験值を示す $\}$

\begin{tabular}{|c|c|c|c|c|c|c|}
\hline \multirow{2}{*}{$\begin{array}{l}\text { 位 } \\
\text { 置 }\end{array}$} & \multicolumn{3}{|c|}{$N=0.0$} & \multicolumn{3}{|c|}{$N=0.2$} \\
\hline & $M_{x}$ & $M_{y}$ & $M_{x y}$ & $M_{x}$ & $M_{y}$ & $M_{x y}$ \\
\hline 11 & $\begin{array}{c}-0.153 \\
(-0.190)\end{array}$ & $\begin{array}{c}-0.055 \\
(-0.062)\end{array}$ & $\left(\begin{array}{l}0.080 \\
0.076\end{array}\right)$ & $\begin{array}{c}-0.081 \\
(-0.103)\end{array}$ & $\begin{array}{c}-0.048 \\
(-0.048)\end{array}$ & $\left(\begin{array}{l}0.075 \\
0.078\end{array}\right)$ \\
\hline 12 & $\left(\begin{array}{l}0.083 \\
0.069)\end{array}\right.$ & $\left(\begin{array}{l}0.000 \\
0.003\end{array}\right)$ & $\left(\begin{array}{l}0.125 \\
0.120\end{array}\right)$ & $\left(\begin{array}{l}0.118 \\
0.105\end{array}\right)$ & $\left(\begin{array}{l}0.002 \\
0.002\end{array}\right)$ & $\left(\begin{array}{l}0.119 \\
0.119\end{array}\right)$ \\
\hline 13 & $\left(\begin{array}{l}0.118 \\
0.117\end{array}\right)$ & $\left(\begin{array}{c}-0.004 \\
(\quad 0.004)\end{array}\right.$ & $\left(\begin{array}{l}0.091 \\
0.085\end{array}\right)$ & $\left(\begin{array}{l}0.132 \\
0.139\end{array}\right)$ & $\left(\begin{array}{r}-0.003 \\
0.004\end{array}\right)$ & 39) \\
\hline 14 & $\left(\begin{array}{l}0.123 \\
0.105\end{array}\right)$ & $\left(\begin{array}{r}-0.003 \\
0.004\end{array}\right)$ & $\left(\begin{array}{l}0.054 \\
0.051\end{array}\right)$ & $\left(\begin{array}{l}0.111 \\
0.109\end{array}\right)$ & $\left(\begin{array}{r}-0.003 \\
0.004\end{array}\right)$ & $\left.\begin{array}{l}0.050 \\
0.048\end{array}\right)$ \\
\hline 15 & $\left(\begin{array}{l}0.065 \\
0.066\end{array}\right)$ & $\left(\begin{array}{c}-0.001 \\
0.005\end{array}\right)$ & $\left(\begin{array}{l}0.024 \\
0.021\end{array}\right)$ & $\left(\begin{array}{l}0.075 \\
0.075\end{array}\right)$ & $\left(\begin{array}{c}-0.001 \\
0.005\end{array}\right)$ & $\left(\begin{array}{l}0.021 \\
0.016\end{array}\right)$ \\
\hline 16 & $\left(\begin{array}{l}0.016 \\
0.019\end{array}\right)$ & $\left(\begin{array}{l}0.003 \\
0.003\end{array}\right)$ & 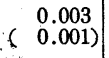 & $\left(\begin{array}{l}0.033 \\
0.032\end{array}\right)$ & $\left(\begin{array}{l}0.003 \\
0.003\end{array}\right)$ & $(-c$ \\
\hline 17 & $\begin{array}{c}0.015 \\
(-0.003)\end{array}$ & $\begin{array}{r}-0.015 \\
(-0.001)\end{array}$ & $\begin{array}{l}-0.0 \\
(-0.0\end{array}$ & $\begin{array}{c}0.024 \\
(-0.004)\end{array}$ & $\begin{array}{c}-0.017 \\
(-0.003)\end{array}$ & $(-c$ \\
\hline 21 & $\left(\begin{array}{l}0.028 \\
0.027\end{array}\right)$ & $\begin{array}{c}-0.020 \\
(-0.004)\end{array}$ & $\left(\begin{array}{l}0.025 \\
0.010\end{array}\right)$ & $\begin{array}{c}-0.006 \\
(-0.027)\end{array}$ & $\begin{array}{l}-0 \\
(-0\end{array}$ & 38) \\
\hline 22 & $\begin{array}{c}-0.026 \\
(-0.010)\end{array}$ & $\left(\begin{array}{l}0.070 \\
0.047\end{array}\right)$ & $\left(\begin{array}{l}0.065 \\
0.065)\end{array}\right)$ & $\left(\begin{array}{l}0.021 \\
0.031\end{array}\right)$ & $\left(\begin{array}{l}0.036 \\
0.023\end{array}\right)$ & $\begin{array}{l}0.083 \\
(0.079)\end{array}$ \\
\hline 23 & $\left(\begin{array}{l}0.070 \\
0.043\end{array}\right)$ & $\left(\begin{array}{l}0.070 \\
0.053\end{array}\right)$ & $\left(\begin{array}{c}0.121 \\
0.117)\end{array}\right.$ & $\left(\begin{array}{l}0.106 \\
0.083\end{array}\right)$ & $\left(\begin{array}{l}0.052 \\
0.039\end{array}\right)$ & $\left(\begin{array}{l}0.122 \\
0.117\end{array}\right)$ \\
\hline 24 & $\left(\begin{array}{l}0.090 \\
0.092\end{array}\right)$ & $\left(\begin{array}{l}0.047 \\
0.046\end{array}\right)$ & $\left(\begin{array}{l}0.095 \\
0.086)\end{array}\right)$ & $\left(\begin{array}{l}0.108 \\
0.107\end{array}\right)$ & $\left(\begin{array}{l}0.042 \\
0.039\end{array}\right)$ & $\left.\begin{array}{l}0.098 \\
0.089\end{array}\right)$ \\
\hline 25 & $\left(\begin{array}{l}0.100 \\
0.092\end{array}\right)$ & $\left(\begin{array}{l}0.025 \\
0.026\end{array}\right)$ & $\left(\begin{array}{l}0.060 \\
0.052\end{array}\right)$ & $\left(\begin{array}{l}0.093 \\
0.092\end{array}\right)$ & $\left(\begin{array}{l}0.028 \\
0.027\end{array}\right)$ & $\begin{array}{l}0.057 \\
\left(\begin{array}{l}0.052) \\
-\end{array}\right)\end{array}$ \\
\hline 26 & $\left(\begin{array}{l}0.053 \\
0.045\end{array}\right)$ & $\left(\begin{array}{l}0.012 \\
0.006\end{array}\right)$ & $\left(\begin{array}{c}0.027 \\
0.022\end{array}\right)$ & $\left(\begin{array}{l}0.062 \\
0.055\end{array}\right)$ & $\left(\begin{array}{l}0.013 \\
0.009\end{array}\right)$ & $\left(\begin{array}{l}0.022 \\
0.018\end{array}\right)$ \\
\hline 27 & $\left(\begin{array}{c}0.001 \\
-0.014\end{array}\right)$ & $\begin{array}{c}-0.045 \\
(-0.034)\end{array}$ & $\left(\begin{array}{l}0.013 \\
0.009\end{array}\right)$ & $\left(\begin{array}{l}0.017 \\
0.000\end{array}\right)$ & $\begin{array}{l}-0.041 \\
(-0.028)\end{array}$ & $\left.\begin{array}{l}0.007 \\
0.018\end{array}\right)$ \\
\hline 31 & $\begin{array}{r}0.015 \\
(-0.009)\end{array}$ & $\begin{array}{c}-0.085 \\
(-0.061)\end{array}$ & $\left(\begin{array}{l}0.028 \\
0.024)\end{array}\right.$ & $\begin{array}{l}0.021 \\
0.003\end{array}$ & $\begin{array}{c}-0.066 \\
(-0.047)\end{array}$ & $\begin{array}{l}0.025 \\
0.017)\end{array}$ \\
\hline 32 & $\left(\begin{array}{l}0.077 \\
0.068\end{array}\right)$ & $\left(\begin{array}{l}0.018 \\
0.018\end{array}\right)$ & $\left(\begin{array}{l}0.045 \\
0.036\end{array}\right)$ & $\left(\begin{array}{l}0.059 \\
0.055)\end{array}\right.$ & $\left(\begin{array}{l}0.020 \\
0.013\end{array}\right)$ & $\left.\begin{array}{l}0.050 \\
0.044\end{array}\right)$ \\
\hline 33 & $\left(\begin{array}{l}0.045 \\
0.052\end{array}\right)$ & $\left(\begin{array}{l}0.072 \\
0.062\end{array}\right)$ & $\left(\begin{array}{l}0.081 \\
0.077\end{array}\right)$ & $\left(\begin{array}{l}0.073 \\
0.073)\end{array}\right.$ & $\left(\begin{array}{l}0.052 \\
0.041\end{array}\right)$ & $\left(\begin{array}{l}0.095 \\
0.091)\end{array}\right.$ \\
\hline 24 & $\left(\begin{array}{l}0.065 \\
0.041\end{array}\right)$ & $\left(\begin{array}{l}0.093 \\
0.076\end{array}\right)$ & $\left(\begin{array}{l}0.115 \\
0.111)\end{array}\right)$ & $\left(\begin{array}{l}0.100 \\
0.086)\end{array}\right)$ & $\left(\begin{array}{l}0.066 \\
0.057)\end{array}\right.$ & $\left(\begin{array}{l}0.123 \\
0.115\end{array}\right)$ \\
\hline
\end{tabular}

ら求めているのに対し，曲げモーメントはたわみの 2 階 微分で求めていること, および, 曲げモーメントを求め るのに使用した三角形要素は，その変位関数が要素間の 境界線上での適合条件を満足していないらえに，曲げモ 一メントが要素間で不連続となっているためであると考 えられる。また, 各要素ごとに節点の曲げモーメントを 求め, これを平均したものをこの節点の曲げモーメント の值としているため，板の内部より周辺の方が精度が悪 くなっている。

\section{5. 弾性的に点支持された斜板の挙動}

A. Mehmel らが行なった実験的研究, および, 著者 らの計算結果より, 弾性的に点支持された斜板では, 斜 角の大きさ, 支点の数, 弾性点支承の軟弱度 (弾性的柔 軟度), 辺長比などが, 支点反力, および, 曲げモーメ ントに大きな影響を与えることが明らかとなった。その 概要を述べると，つぎのとおりである。

(1), 表一1 から明らかなように, 斜板は満載等分布 荷重が作用すると, 支点反力は鈍角端の支点へ大きく集 

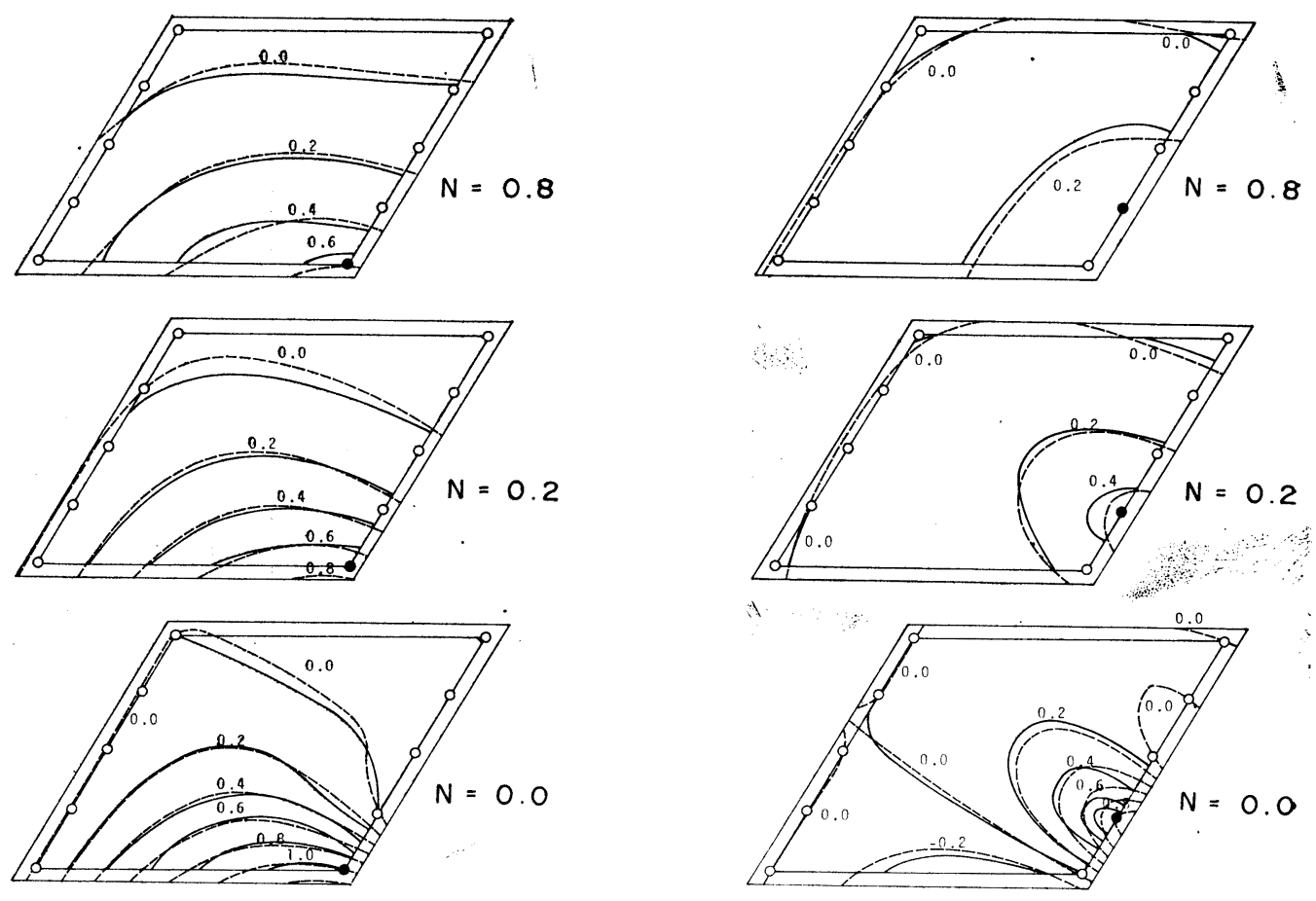

鈍角端の支点

鈍角端のつぎの支点
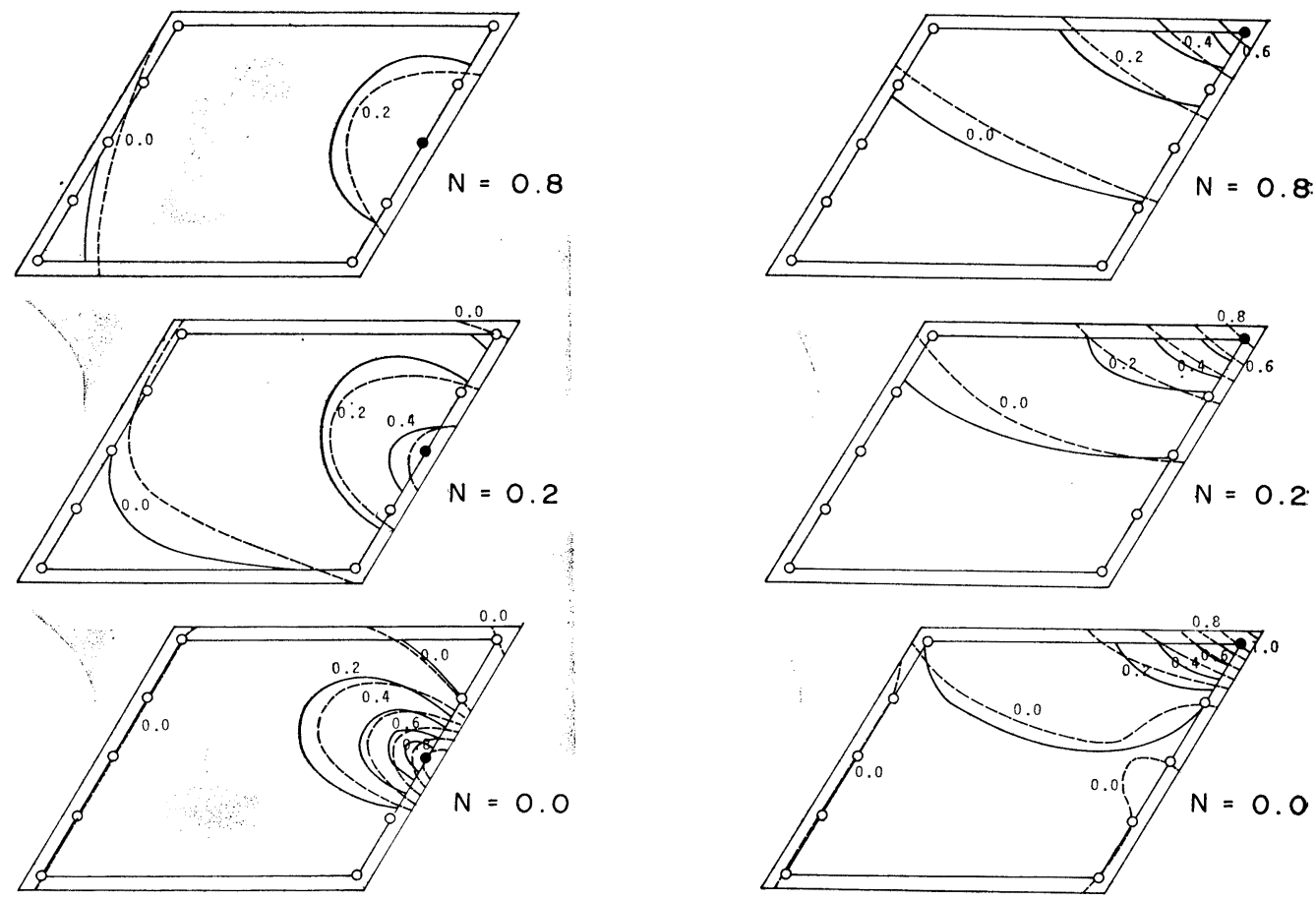

中間支点

鋭角端の支点

図一2 辺長比 $l_{\varphi} / l=1.0$, 斜角 $\varphi=60^{\circ}$, 支点数 $n=5$ の場合における, 支点反力の影響面 （実線は計算値, 点線は実験值を示す） 
$n=3$

$n=5$

$n=9$
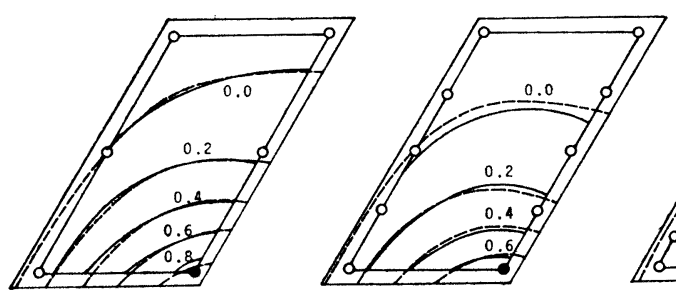

鈍角端の支点

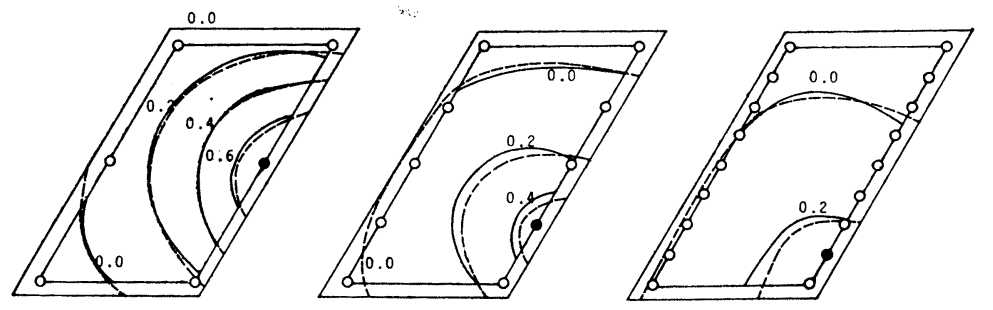

鈍角端のつぎの支点

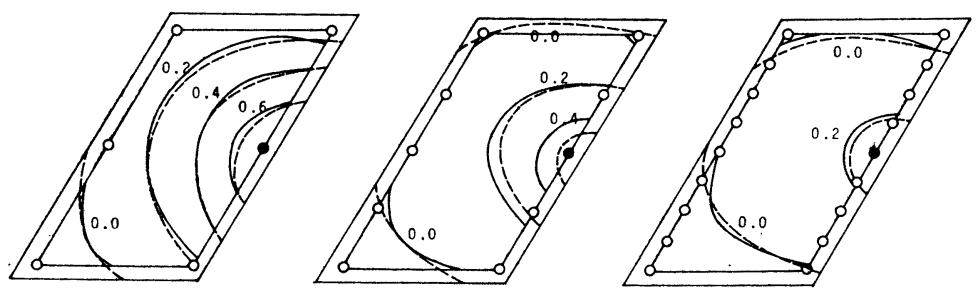

中間支点

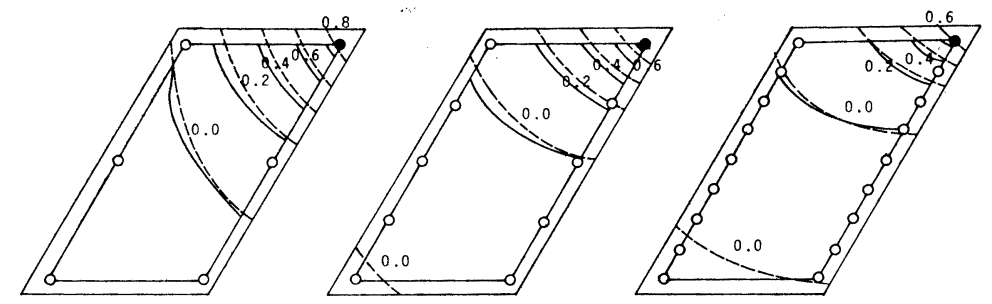

鋭角端の支点

図一3 辺長比 $l_{\varphi} / b=0.5$, 斜角 $\varphi=60^{\circ}$, 弾性的柔軟度 $N=0.2$ の場合における, 支点反力の影響面（実線は計算値, 点線は実験值を示す)）
のつぎの支点での反力の対比がい っそらはっきりしたものになり， 荷重分配の上から明らかに不利と なるが，弾性的に支持された場合 には，鈍角端の支点も含めて， 個々の支点の反力が減少してい く。図一3 は, 弾性的柔軟度 $N=$ 0.2 の場合について, 支点数 $n$ の 変化による影響面の変化を示して いる。支点数 $n$ が増加するととも に, 各支点とも, 等高線の本数が 減少していくのが，はっきり見ら れる。

(3) 曲げモーメントについて は, A. Mehmel らの実験には, あまりくわしく示されていない が, 著者らの計算結果をまとめる と,つぎのようになる。

a) 図一4 は, 辺長比 $l_{\varphi} / b=$ 1.0 , 斜角 $\varphi=60^{\circ}$, 支点数 $n=5$ の 斜板の中央点における曲げモーメ ント $M_{x}, M_{y}$, および, ねじり モーメント $M_{x y}$ の影響面である。 弾性的柔軟度 $N=0.0$ (剛支持) の場合と, $N=0.2$ の場合が示さ

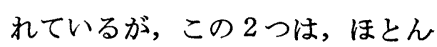
ど同じで, 板中央点においては, 曲げモーメントの影響面は, 弾性 的柔軟度 $N$ には, あまり左右さ れない。

b）図一5 は，鈍角端における 曲げモーメントの影響面である。 弾性的に支持されている場合に は, 剛に支持されている場合にく らべて, 曲げモーメントの最大 值, あるいは, 最小值が小さくな っており，弾性支承が支点反力を
中する傾向が見られる。剛に支持した場合には，この度 合は著しく, また, 鈍角端のつぎの支点では, 逆に, 支 点反力は非常に小さくなるといら傾向を示す。

これに対して, 弾性的に支持された場合には, 支承の 軟弱度が増加するとともに, 鈍角端への反力の集中は緩 和され, 鈍角端のつぎの支点での 浮き上りもなくなっ て, 支点間相互の反力のばらつきは全体に小さくなり, 平均化される傾向が認められる。

（2）支点数 $n$ が増加すると, 剛に支持されている 場合には，（1）で述べたような, 鈍角端の支点と鈍角端
平均化させたのと同様に，鈍角端のような支点に対して は, 曲げモーメントを平均化させる効果のあることを示 している。

\section{6.あとがき}

著者らは, 数值解析が困難であるため, 従来, 実験的 にしか研究されていなかった, 弾性的に点支持された斜 板を, 有限要素法を用いることにより, 容易に数值解析 できることを示した。この数值解析の結果は, A. Meh- 
Mx $\quad \mathrm{N}=0 \mathrm{O}$
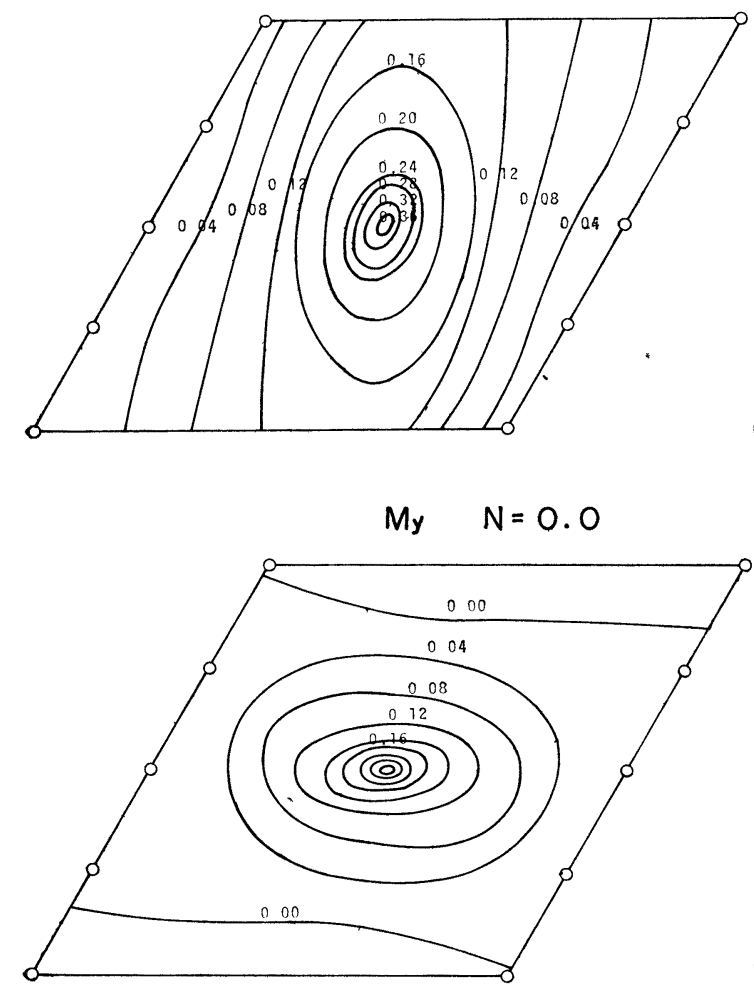

Mxy $N=0.0$

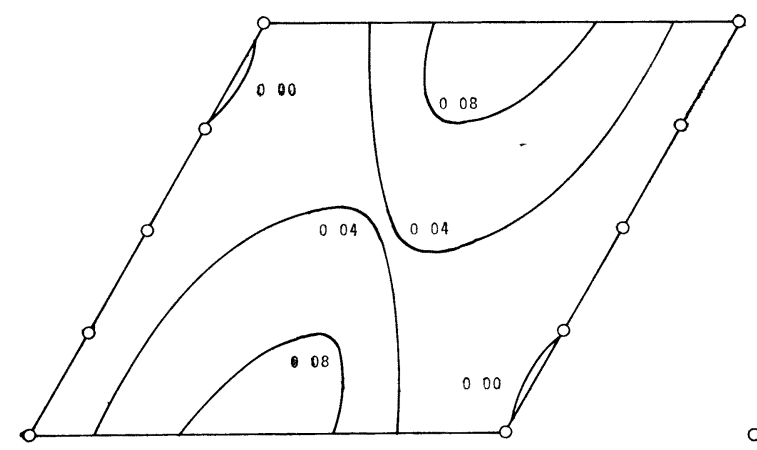

図-4 辺長比 $l_{\varphi} / b=10$, 斜角 $\varphi=60^{\circ}$, 支点数 $n=5$ の場合における,

板の中心点の $\boldsymbol{M}_{x}, \boldsymbol{M}_{y}, \boldsymbol{M}_{x y}$ の影䭓面 (単位 $\mathrm{kp} \cdot \mathrm{cm} / \mathrm{cm}$ )

mel らの実験值とよく一致し，この方法が，このような 問題の解析に対する有効な手段であることが明らかとな った。

著者らは, A Mehmel の実験との対比を目的とし て,この数值解析の研究を 1 スパンの斜板に対して行な ったが,さらに，2 スパン， 3 スパン連続の斜板に対し $\tau$, 斜角 $\varphi$, 辺長比 $l_{\varphi} / b$, 支点数 $n$, 弾性的柔軟度 $N$ の 種々の組み合わせの場合の数值解析を行なっており, 近 く公表したいと考えている。
Mx $\quad N=0.2$

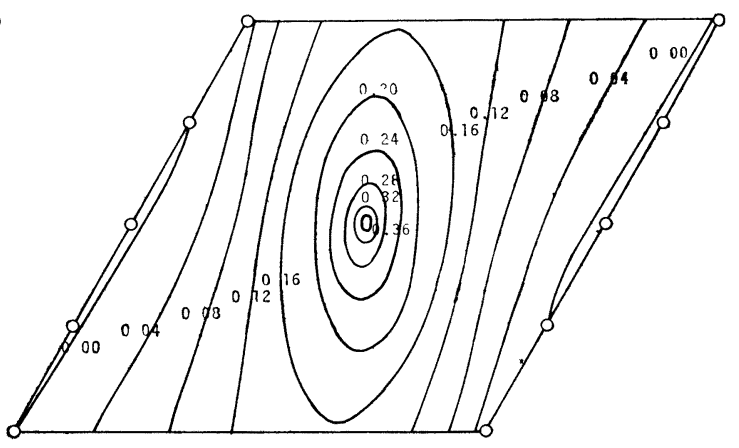

My $N=0.2$

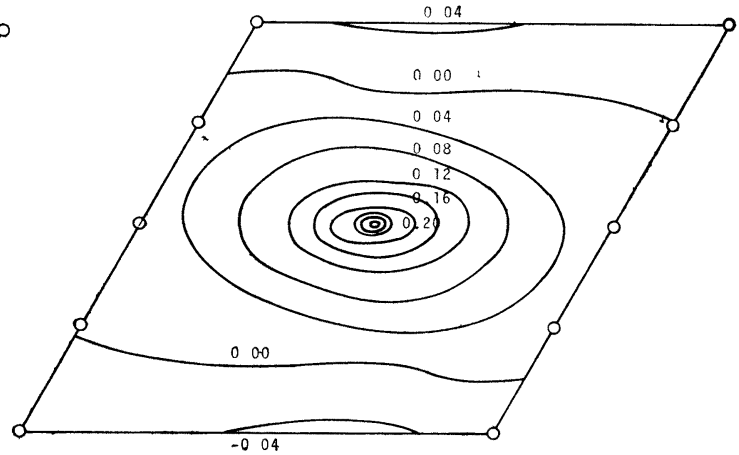

Mxy $\quad N=02$

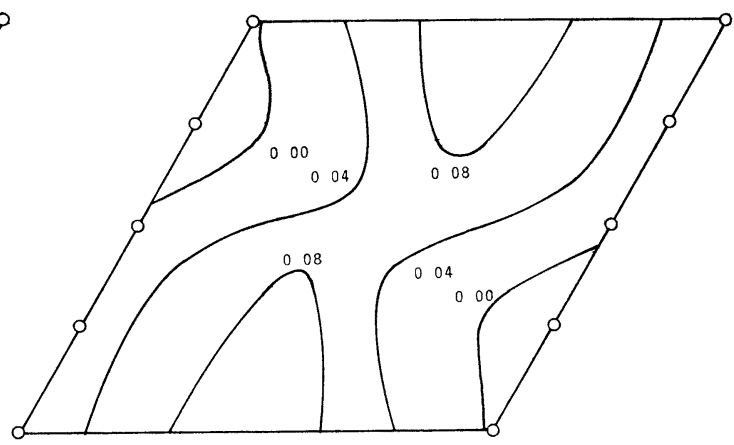

斜板がスラブ橋として用いられることが，ますます多 くなり，また，このスラブ橋が支承において線支承では なく，ネオプレーンなとによって点支持されていること が多くなってくる傾向に対し，この拙い報告が多少なり とも貢献するところがあれば，幸甚である。

この研究は, (株) 福山コンサルタント代表取締役 福 山俊郎氏の示唆によるところが多い。ここに記して, 謝 意を表したい。

この数値計算には, 京都大学大型計算機 センターの 
$-M x \quad N=0.0$
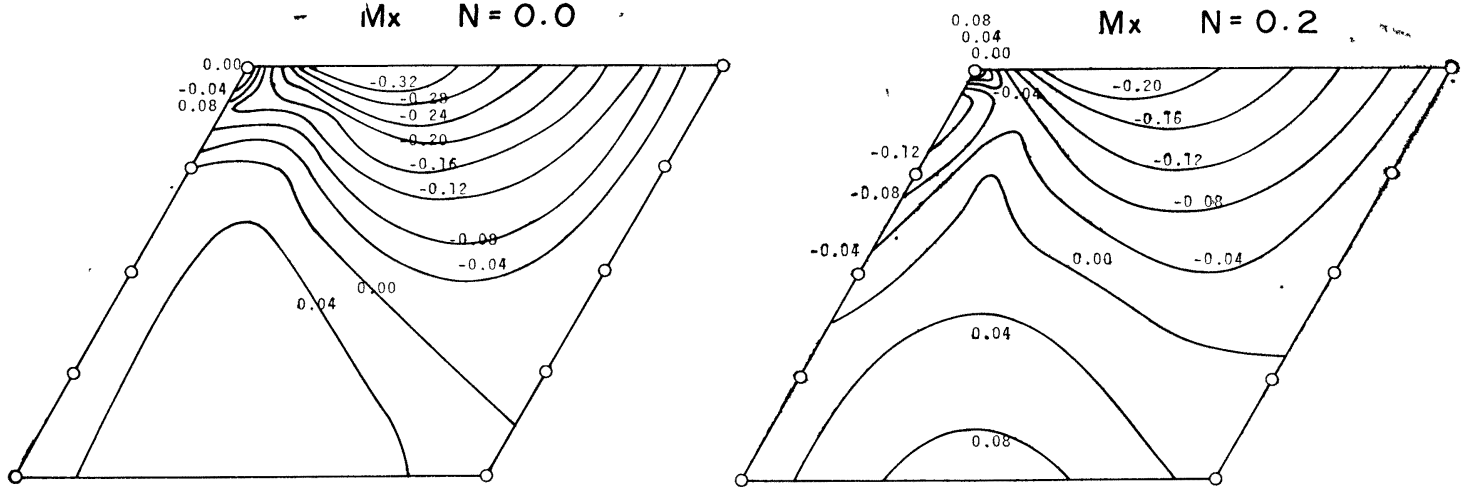

My $\quad N=0.0$

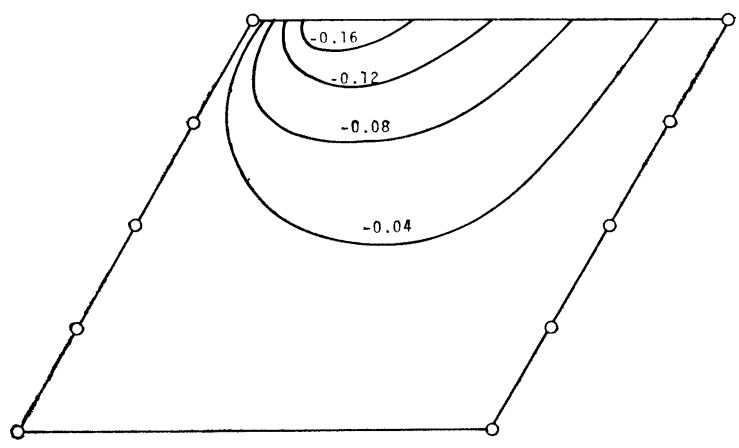

My $N=0.2$

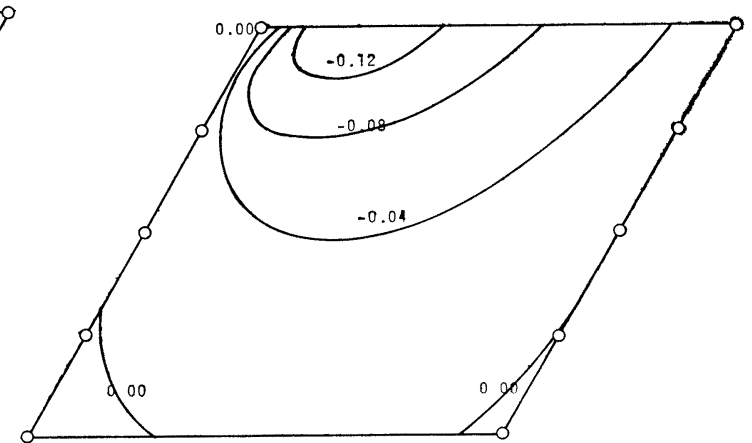

Mxy $\quad N=0.0$.
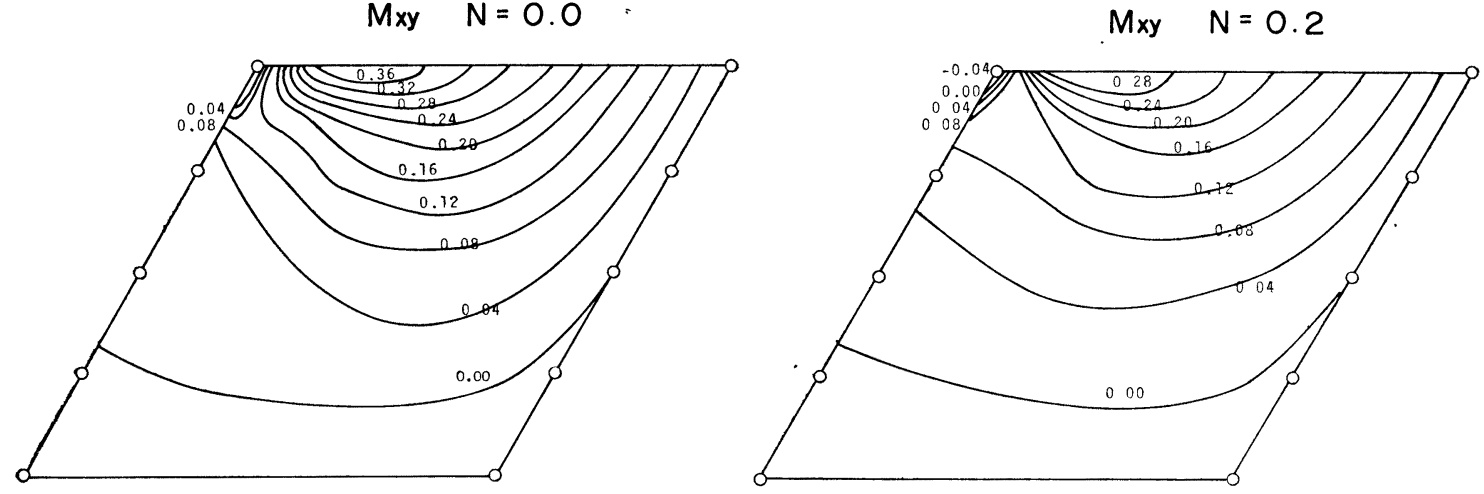

図-5 辺長比 $l_{\varphi} / b=1.0$, 斜角 $\varphi=60^{\circ}$, 支点数 $n=5$ の場合における, 鈍角端の $\boldsymbol{M}_{x}, \boldsymbol{M}_{y}, \boldsymbol{M}_{x y}$ の影響面 (単位 $\mathrm{kp} \cdot \mathrm{cm} / \mathrm{cm}$ )

FACOM 230-60 を使用した。

\section{参考 文 献}

1) A. Mehmel u. H. Weise : Modellstatische Untersuchung punktförmig gestützter schiefwinkliger Platten unter besonderer Berücksichtigung der elastischer Auflagernachgiebigkeit, Deutscher Ausschuss für Stahlbeton, Heft 161 (1964).

2) H. Homberg, R. Marx u. H. Jäckle : Einfluss einer elastischen Lagerung auf Biegemomente und Auflagerkraft Schiefwinkliger Einfeldplatten, Bauingenieur, 36 (1961), S. 19-26.

3) W. Andrä u. F. Leonhardt : Einfluss des Lagerabs- tandes auf Biegemomente und Auflagerkräfte schiefwinkliger Einfeldplatten, Beton und Stahlbetonbau, 55 (1960), S. 151-162.

4) 山本・福山・西辻・成岡 : 鉄笳 ニンクリート 斜スラブ橋 の設計, 土木学会誌, 51-10 (昭和 41.10), pp. 22〜27.

5）赤井・堀井・石川：斜版の反力測定実験，橋梁，5-8（昭 和 44.8 ), pp. $48 \sim 54$.

6) G.P. Bazeley, Y.K. Cheung, B.M. Irons and O.C. Zienkiewicz: Triangular element in plate bending, conforming and non-conforming solutions, Proc. Conf. on Matrix Method in Structural Mechanics, WrightPatterson Air-Force Base, Ohio, 1965, pp. 547-575.

(1970.5.11 • 受付) 